\title{
Impact of Flexible Work Arrangements on Job Satisfaction Among the Female Teachers in the Higher Education Sector
}

\author{
Mayeesha Fairuz Rahman \\ Southeast Business School, Southeast University, Dhaka, Bangladesh
}

\begin{abstract}
A remarkable growth of female participation has been observed in the job market of Bangladesh over the past few years. The number of female employees and their contribution is likely to increase further with the pace of the country's development in terms of the literacy rate and employment scope. Among the several thriving sectors of the country, the significance of the education sector especially in the tertiary level is highlighted by the noble contribution they make to the economy. Due the rapid increase in the number of private universities over the past few years in the country, quite a large number of women have chosen to embark on this field with the hopes of establishing themselves as academicians. However, one of the existing impediments which obstructs several women to reach their zenith professionally is rigid company policies specifically lack of flexibility. The importance of Flexible Work Arrangements (FWA) has recently gained the attention of academicians as well as practitioners to improve employee performance. Since participation of women in a noble sector like education is highly desired; hence, the present study aims to investigate the relationship between Flexible Work Arrangements (FWA), Employee Job satisfaction and Work-life Balance of the female teachers in the higher education sector of the country. Based on the analysis of diverse literature from the secondary data, hypotheses were developed and in order to test those, primary data had been collected, responses from 203 female teachers were analyzed through SPSS. The findings have confirmed that FWA have positive and significant impact both on Employee Job Satisfaction and Work-life Balance as well as Work-life Balance has a positive impact on Job Satisfaction. However, one of the elements of FWA, namely, Compressed Workweek, is found to have values lower than the significance level after performing regression analysis.
\end{abstract}

Keywords: Flexible Work Arrangements (FWA), Work-life Balance, Job Satisfaction, Female employees and Education Sector

DOI: $10.7176 / E J B M / 11-18-11$

Publication date: June $30^{\text {th }} 2019$

\section{Introduction:}

Flexible Work Arrangements (FWA) and family policy practices to improve work-life balance have become imperative in the context of human resource management since the 1970s (Paull, Omari and Sharafizad, 2009). The focus is seen to shift from depriving or exploiting workers for getting the work done to facilitating employees in order to become the 'employer of choice'. Human resource management can build a strong connection between employees and organizational goals by incorporating flexibility in work Apgar (1998). Also, integrating flexible work arrangements do not only aid in boosting employee objectives, these will in turn help the organizations to attain their long term goals more effectively and efficiently. In order to cope up with the dynamic business world and employee needs, firms are continually seeking for ways to develop a culture that facilitates the employees to manage work-life balance which will lead to higher job satisfaction and maximized employee productivity. Hence, it is advised that firms should strive to come up with new yet cost effective means of satisfying their employees' needs (Barber, Laing and Simeone, 2005). It is generally perceived that Flexible Work Arrangements (FWA) can satisfy all the employees, however, when women are concerned, it is presumed that these factors will substantially aid the several working women to strike a balance between their personal and professional lives. According to Byron (2005), women are likely to benefit the most from FWA; as a result, this phenomenon merits closer attention within this literature.

According to the International Labor Organization's (ILO) flagship report titled "World Employment and Social Outlook", the total number of working women has been found to be 18.1 million in Bangladesh in 2018, covering $28.4 \%$ of the total workforce, (Ovi, 2018). Hence, this segment needs to be utilized properly as they cover of a significant proportion of labor force and can work to contribute for the socio-economic growth of the country. Among the several flourishing sectors, the higher education has also become one of the lucrative sectors for employment among the women. According to the website of University Grants Commission of Bangladesh, there are 103 private universities and 41 running public universities in Bangladesh (University Grants Commission of Bangladesh, n.d.); where the number of teachers is 29356 in the tertiary level, with the number of female teachers being 7771 ("Bangladesh Education Statistics 2018(New)", 2018) A large number of women are working as teachers in this field and many among them, from diversified sectors including education have reported difficulties in balancing their career and personal lives due to rigid working hours ,disharmony at home and so on (Anuradha and Pandey, 2016, Pahuja, 2016, Sundaresan, 2014, and Kumari 2012); according to a study by the Families and 
Work Institute, around $45 \%$ of the women have reported some or a lot of stress related to workplace-family life balance as cited by (Meenakshi, Subrahmanyam and Ravichandran, 2013). In response many organizations and academic institutions including universities are feeling the need to adopt some sort of flexible arrangements in work to retain qualified employees (Sharafizad, Paull and Omari, 2011). Hence, this study emerged to examine the impact of flexible work arrangements on work-life balance and job satisfaction among women employed in a noble sector like higher education as well as to find out which factors of FWA have greater influence on job satisfaction. This paper is expected to contribute both academically and practically to the better understanding of how FWA like flextime schedules and telecommuting can affect work-life balance and the overall job satisfaction levels of the women which is anticipated to provide some meaningful insights to the universities so that they can execute better planning and adopt the right mechanisms to attract, hire and retain a qualified pool of female employees. Finally, it will give an idea regarding the working practices of the universities to those wishing to establish their careers in this sector.

\section{Literature Review:}

2.1. Practice of Flexible Work Arrangements in organizations:

FWA had been defined as "alternative work options that allow work to be accomplished outside of the traditional temporal and/or spatial boundaries of a standard workday" (Rau and Hyland, 2002, p.117). According to Workplace Flexibility (2010), FWA can be considered as "any one of a spectrum of work structures that alters the time and/or place that work gets done on a regular basis." Also, it is considered as work options with flexibility regarding where and when a work is performed (Rau and Hyland, 2002). With the shift of employee mindset inclining towards more flexible work options, organizations are also incorporating more flex work options in order to attract and retain the talented pool of employees and maintain a competitive market position (Rawashdeh, Almasarweh and Jaber 2016). FWA have been proven to improve employee morale and contribute greatly to the firms (Cole, 2006), hence, many firms in various industries are adopting such practices. Is has been recommended by Scordato and Harris (1990) that FWA can be effectively used for the positions like human resource generalist, international manager, counselor, line jobs, supervisory positions, network designer, information specialist and so on. Among the several types of FWA, flextime schedule is one of the arrangements that allows an employee to choose his/her preferred start and end time, but fulfill the required number of working hours per day, and be at work during the core hours of a day, however, the extent of variations in flextime programs are usually given by the firms (Grantham, Swanberg and Johnson, 2009). In other words, flextime schedules are made based on the needs of the employees, within given parameters approved by the supervisor ("Workplace Flexibility", 2010) Under such an arrangement employees are allowed to arrive before the core start time and leave after the core finish time, however, usually, there is a limit on how early workers can come and how late they can leave the office (Baltes, Clark and Chakrabarty, 1999). One of the benefits of such practices is that these allow employers to operate beyond the traditional working hours. Also, overtime costs can be saved by allowing workers to work with flexibility as well as it gives the employees a certain level of autonomy. However, scheduling trainings and meetings can be very difficult while practicing flextime in the organization and there could be lack of supervision for those who work during nonconventional hours (Scott, n.d). Other significant advantages include improved commuting, decreased tardiness, improved coordination of on- and off-job responsibilities, improved employeremployee relationship, increased job satisfaction, and improved productivity (Ralston, 1989). Another, common FWA is compressed workweek where the workweek is reduced and employees get the privilege of working fewer than 5 days, by increasing the number of hours an employee is required to work each day (Baltes, Clark and Chakrabarty, 1999); for instance, they can work for four 10-hour days or even three 12-hour days instead of traditional five 8-hour days a week (Rawashdeh, Almasarweh and Jaber 2016). This arrangement is appreciated for allowing employees to do full-time work yet giving them the opportunity to experience a longer period of uninterrupted personal time, as a result, reducing the rate of absenteeism from workplace (Ronen and Primps, 1981). Moreover, telecommuting is another FWA which allows workers to perform their task from outside the office premises with the aid of telecommunications technology (Nilles, 1988) or computers (Mamaghani, 2006). This strategy is gaining wide acceptance in the United States, the United Kingdom, the Netherlands, Germany and elsewhere in Europe (Mokhtarian, 1991). Finally, job sharing is another popular arrangement that allows two people to share one full-time job, each with divided responsibilities, salary and benefits including sick leaves and holidays (Gholipur et al, 2010). An example could be one employee coming to work and completing a shift of 8 A.M.-12P.M. and another starting from 1 P.M. and finishing at 5P.M. Interestingly, teaching was one of the first jobs done by job sharing because even back in the 1970s teaching was very popular among women who wanted to work yet maintain a proper family life (Eick, 2002). However, there is very little evidence regarding the practices of such FWA in the teaching sector of Bangladesh, where beside the primary and secondary level numerous women are working in the higher education sector, i.e., university level as full-time teachers. 


\subsection{Flexible Work Arrangements and Work-life Balance:}

Work-life balance has generated a lot of interest in the field of research especially among those who are concerned about the quality of working life and its relation to broader quality of life (Guest, 2002). Greenhaus and Allen (2006), defined work-life-balance as 'the extent to which an individual's effectiveness and satisfaction in work and family roles are compatible with the individuals' life role priorities at a given point in time'. According to Kalliath and Brough (2008), employees need to readjust to multiple demands throughout their period of employment, hence, it is a continual method, i.e., the level of work-life balance can change over time, as a result, came up with the following definition "Work-life balance is the individual perception that work and non-work activities are compatible and promote growth in accordance with an individual's current life priorities" (p. 326). Since the level of work-life balance is expected to change overtime, a question of flexibility in work arrangement arises in order to facilitate the workers for striking a proper balance between work and life. According to a research by Shagvaliyeva and Yazdanifard (2014), flexibility in work positively influences work-life balance and that employee wellbeing is a positive outcome of work-life balance. According to Frank and Lowe (2003), most of the employees have a need of flexibility in their work schedule to strike a balance between their work and family issues. In a study of (Gregory and Milner, 2009), it has been found that organizations have an important role to play for improving the employees' balance between work and life as individual choice regarding work life balance is constrained by organizational culture and national gender cultures. Workplace practices emphasizing on flexibility that can facilitate employees by reducing work-family conflict have recently received a great amount of interest among the researchers and practitioners (Hammer et al, 2005). Moreover, such practices are considered to be popular tools that can help individuals maintain a balance between their work and family responsibilities (Allen, et al, 2013). Additionally, several scholars such as (Allen et al, 2013, Palmeri, 2013 and Culberth, 2010) have found positive association between FWA as independent variables and dependent variables like job satisfaction and work-family balance. Also, from the employer's point of view, if the employees can fulfill both their working and non-working roles properly, they will be highly satisfied resulting in better performance, greater commitment, lower absenteeism and lower turnover, however, trust between the employer and employee is the key here as, if not monitored, flexible working practices might create even more difficulties (Shagvaliyeva and Yazdanifard, 2014). In addition, although flexible working practices are being widely embraced by employees as they allow them to prioritize, some of the cons of the system, if not controlled and monitored carefully might include errors due to communication problems, minimized staffing levels, isolation of work and so on (Maxwell et al, 2007). However, as it has been found in several studies that most of the FWA especially flextime schedules are significantly helping to improve work-life balance (Allen, 2001, McNall et al, 2010 and Palmeri, 2013), it has been advised that management carefully incorporates such practices inside their organizations (Rawashdeh, Almasarweh and Jaber 2016). Intriguingly, it has been found that men generally perceive flexible working practices as a means of developing their organizational commitment, whereas women see flexibility as an opportunity to improve work-life balance (Hofäcker \& König, 2013).Since a lot of women are now interested to work, yet maintain their family roles, it is important to understand how the women balance their professional and domestic lives (Narayana and Neelima, 2017). Also, it has been found that some women working in organizations with a paternalistic culture and high structural constraints, disruptive to their family maintenance, tend to find loopholes to bypass organizational norms. Hence, this study aims to find the important factors regarding the FWA that will aid the working women to continue their career and personal lives simultaneously.

\subsection{Flexible Work Arrangements and Job Satisfaction:}

FWA are gaining immense popularity and these definitely have substantial impact on Job Satisfaction of employees. Job Satisfaction is undoubtedly one of the essential factors for employee motivation and better performance (Raziq and Maulabakhsh, 2015). Employee job satisfaction is a widely used term in the field of human resources and is associated with employee emotions i.e. how people think, feel and observe their jobs while performing at their workplaces (Vroom, 1964 and Spector, 1997). In the present era of globalization, the organizations are facing multiple challenges to keep up with the pace and remain competitive in the market and as we know human capital is the key asset of an organization (Fulmer \& Ployhart, 2013), it is imperative to keep the employees motivated and engaged which can be possible by creating a work environment that will foster employee performance at workplace yet enable them to maintain work-life balance (Rane, 2011). A lot of organizations are seen to practice FWA as these arrangements are seen to boost the employee satisfaction level. According to McNall, Masuda and Nicklin (2009), the presence of FWA such as flextime and compressed workweek at organizations make employees feel much enriched, which in turn, results in higher job satisfaction. FWA can benefit both the employers and the employees and the benefits include higher commitment, lower turnover, reduced work-family conflict, higher autonomy and higher job satisfaction (Omondi and K'Obonyo, 2018).

Although several male employees are now utilizing flexible time schedules, it is still much more prevalent among the women in the workplaces and it results in increased employee loyalty and engagement as well as higher job satisfaction; however, proper controlling mechanisms are required to prevent further difficulties in the workplace (Shagvaliyeva and Yazdanifard, 2014). Researchers also suggest that, there is a positive relationship 
between telecommuting and job satisfaction as employees get the opportunity to satisfy their personal needs by adjusting job responsibilities (Bélanger, 1999 and Norman et al, 1995). However, according to the findings of Golden and Veiga (2005), gains in job satisfaction due to telecommuting are highly significant at initial levels but tend to be lower at higher levels of usage. Also, the practice and benefits of telecommuting can be questioned as technology cannot fully substitute the experience of working together onsite (Shapiro, et al, 2002). In addition, according to some research, implementation of compressed workweek can result in positive changes in job attitude and higher job satisfaction as it presents with higher workers' independence (Pierce et al, 1989 and Baltes et al, 1999). According to a report of Bureau of Labor Statistics, the share of women in labor force is projected to increase between 2014 and 2024; however, they are still not immune from unfair treatment in the workplace (Agarwal, 2018). Since the number of educated women has increased substantially and they now comprise a large proportion of the total employment sector including education in Bangladesh, (Khatun, 2018), it is crucial to find out ways to retain this potential talented pool of employees for the socio-economic development. In order to do so, it is pivotal to ensure that these women are satisfied with their jobs as only satisfied employees can perform productively through increased commitment levels (Rane, 2011); owing to the paramount importance of job satisfaction, it can be said that more research is needed to find out ways to incorporate FWA for women in the workplace as these practices have prominent impact on positive attitude towards job. While there are studies highlighting the benefits and suggesting the practice of FWA (Omondi and K'Obonyo, 2018, Kotey, 2017 , Rawashdeh, Almasarweh and Jaber 2016, Russell, O'Connell \& McGinnity, 2007), however, little research has been done which shows the impact and practice of such practice among women employed in the higher education sector in Bangladesh even though more than 29000 female teachers are employed in this sector combining the public and private universities othe counrty ("Bangladesh Education Statistics 2018(New)", 2018).

From the findings of the literature above, the following hypotheses have been developed to conduct this study: H1: There is a positive relationship between Flexible Work Arrangements (FWA) and Work-life Balance.

$\mathrm{H} 2$ : There is a positive relationship between Work-life Balance and Job Satisfaction.

H3: There is a positive relationship between Flexible Work Arrangements (FWA) and Job Satisfaction.

\section{Research Methodology:}

The study aims to examine the relationship of FWA with work-life balance and job satisfaction; owing to which 3 hypotheses have been developed as mentioned earlier. In order to test the hypotheses developed after critically reviewing prior related researches, primary data were collected using a structured, close-ended questionnaire. The survey instrument was constructed in the form of likert-scale with the help of secondary data gathered from previous studies with values ranging from "1" (i.e. Strongly Disagree) to "5" (i.e. Strongly Agree). The questionnaire comprised of three segments sections with the first focusing on the background information of the respondents (i.e. age, income level, job duration, designation), whereas the second part focused on the main components of FWA (i.e. flextime schedule, compressed workweek, telecommuting and job sharing), work-life balance and their job satisfaction. In addition, the segment $C$ was developed to gather insights from the respondents' perspectives that which sector would they rather choose to work in if they based their decisions on the dimensions of flexibility in work and work-life balance.

While preparing the second segment of the questionnaire with 31 variables, the factors have been adapted with some modifications from the prior study of Rawashdeh, Almasarweh and Jaber (2016) on flexible work arrangement. For sampling purpose in order to generate data, both convenience sampling and random sampling have been used. As part of the convenience sampling, self-administered survey by the means of Google Forms were provided to some female teachers known personally by the researcher and the rest of the forms were distributed randomly to the female teachers of multiple private universities in the three major cities of Bangladesh found through social media platforms namely Facebook and Linkedin. From a total of 290 distributed questionnaires, only 214 were returned, however, some extreme/incomplete and dubious responses could be found which were then discarded and 203 were finalized. Along with the Mean and Standard Deviation of the responses of the surveyed teachers, reliability of constructs was tested using Cronbach's Alpha to examine the consistency between the constructs. Eventually, in order to investigate the study and test the hypotheses, Regression Analysis was carried out using SPSS version 24. In addition to the above-mentioned methods, Frequency Analysis was used to comprehend the profile of the respondents and explore the sectors where they believe have strong practice of FWA and there is a possibility to maintain a proper work-life balance. 


\section{Data Analysis}

Table 1: Information of the Respondents

\begin{tabular}{|l|l|l|l|}
\hline Variable & Category & Frequency & Percentage (\%) \\
\hline Age & $20-30$ & 57 & 28.1 \\
& $31-40$ & 113 & 55.7 \\
& $41-50$ & 24 & 11.8 \\
& Above 50 & 9 & 4.4 \\
\hline Designation & Lecturer & 93 & 45.8 \\
& Senior Lecturer & 36 & 17.7 \\
& Assistant Professor & 44 & 21.7 \\
& Associate Professor & 19 & 9.4 \\
& Professor & 11 & 5.4 \\
\hline Income Level (in BDT) & Below BDT 30,000 & 12 & 5.9 \\
& BDT30,000-BDT 40,000 & 33 & 16.3 \\
& BDT 41,000-BDT 50,000 & 69 & 34.0 \\
& BDT 51,000- BDT & 61 & 30.0 \\
& $1,00,000$ & 28 & 13.8 \\
& Above BDT 1,00,000 & & \\
\hline Job Duration & $<1$ year (less than 1 year) & 32 & 15.8 \\
& 1-2 years & 57 & 28.1 \\
& 3-4 years & 53 & 26.1 \\
& 5-6 years & 37 & 18.2 \\
& $>7$ years & 24 & 11.8 \\
\hline
\end{tabular}

Table 1 illustrates some basic information of the respondents, which exhibits that majority of the respondents, i.e. $55.7 \%$ fall into the age group of 31-40. Most of the female teachers surveyed have a monthly income level between BDT 41,000 and BDT 50,000 as well as a noteworthy proportion of the respondents earns BDT 51,000BDT 1, 00,000 which is a satisfactory income range in the context of Bangladesh. When asked about their job tenure, it has been found that $28.1 \%$ of them have been working in their current institution for $1-2$ years and most of the women are lecturers with a percentage of 45.8, whereas only $11.8 \%$ of them are working for more than 7 years and the lowest percentage consists of professors i.e. 5.4, indicating a significant attrition rate.

Table 2: Descriptive Statistics- Mean and Standard Deviation

\begin{tabular}{|l|l|l|l|}
\hline \multicolumn{2}{|l|}{ Flextime Schedule } & Mean & Std. Deviation \\
\hline \multicolumn{2}{|l|}{ N } \\
\hline My job does not have rigid start and end times. & 4.05 & .676 \\
\hline My job requires me to work for certain number of hours per day/week. & 3.85 & .772 \\
\hline $\begin{array}{l}\text { My job gives me the flexibility to choose my start and end times by } \\
\text { fulfilling the mandatory core hours. }\end{array}$ & 3.92 & .737 \\
\hline $\begin{array}{l}\text { My job allows me to leave an hour earlier if I can cover it up on another } \\
\text { working day in that week. }\end{array}$ & 3.97 & .829 \\
\hline My productivity at work is greater due to flexible working hours. & 3.88 & .744 \\
\hline Compressed Workweek & Mean & Std. Deviation \\
\hline & 3.77 & .856 \\
\hline I have the option to work fewer than 5 working days. & 203 \\
\hline $\begin{array}{l}\text { I have to work for 9 or more hours each day for availing an extra day off } \\
\text { in the week unlike the traditional working hours. }\end{array}$ & 3.53 & .913 \\
\hline $\begin{array}{l}\text { I have the option to take mini breaks during work when I work for such } \\
\text { long hours. }\end{array}$ & 3.72 & .870 \\
\hline I have to be present during the core working days at office. & 3.51 & .914 \\
\hline $\begin{array}{l}\text { I have been able to increase my engagement levels at work due to the } \\
\text { opportunity of compressed workweek. }\end{array}$ & 3.57 & .873 \\
\hline
\end{tabular}




\begin{tabular}{|c|c|c|c|}
\hline \multicolumn{4}{|l|}{ Telecommuting } \\
\hline & Mean & Std. Deviation & $\mathrm{N}$ \\
\hline I prefer telecommuting over traditional working arrangements. & 3.91 & .729 & \multirow[t]{4}{*}{203} \\
\hline $\begin{array}{l}\text { I get the opportunity to work from out of office with the aid of technology } \\
\text { for a certain number of hours each week. }\end{array}$ & 3.41 & 1.018 & \\
\hline $\begin{array}{l}\text { It can be much convenient to integrate work and life due to } \\
\text { telecommuting. }\end{array}$ & 4.03 & .734 & \\
\hline $\begin{array}{l}\text { I do not think that telecommuting acts a barrier to career advancement } \\
\text { anymore in the } 21 \text { st century. }\end{array}$ & 3.72 & .865 & \\
\hline \multicolumn{4}{|l|}{ Job Sharing } \\
\hline & Mean & Std. Deviation & $\mathrm{N}$ \\
\hline $\begin{array}{l}\text { It is possible to split my position and responsibilities with someone else in } \\
\text { my workplace. }\end{array}$ & 3.13 & 1.011 & \multirow[t]{4}{*}{203} \\
\hline $\begin{array}{l}\text { It is possible to generate better ideas and contribute more if two people are } \\
\text { sharing the same position. }\end{array}$ & 3.72 & .793 & \\
\hline $\begin{array}{l}\text { I would not mind the income and other benefits which need to be sacrificed } \\
\text { due to sharing my job with another person as I would get more personal } \\
\text { time. }\end{array}$ & 3.45 & .991 & \\
\hline $\begin{array}{l}\text { It is possible to understand and connect with others in a much better way } \\
\text { if the organization practices job sharing method. }\end{array}$ & 3.92 & .870 & \\
\hline \multicolumn{4}{|l|}{ Work-life Balance } \\
\hline & Mean & Std. Deviation & $\mathrm{N}$ \\
\hline $\begin{array}{l}\text { FWA should be practiced in every organization for employees to maintain } \\
\text { a better work-life balance. }\end{array}$ & 4.22 & 679 & \multirow[t]{7}{*}{203} \\
\hline $\begin{array}{l}\text { My institution is flexible with its employees to avail early leaves/late entry } \\
\text { for personal emergencies. }\end{array}$ & 3.67 & .910 & \\
\hline $\begin{array}{l}\text { My institution allows its employees to avail their earned leaves without } \\
\text { much hassle. }\end{array}$ & 3.52 & .930 & \\
\hline $\begin{array}{l}\text { My institution gives assurance to its employees to return to their jobs after } \\
\text { maternity leaves. }\end{array}$ & 3.44 & .944 & \\
\hline $\begin{array}{l}\text { My working arrangements allow me to spend time with my family and } \\
\text { friends after work. }\end{array}$ & 3.75 & .861 & \\
\hline $\begin{array}{l}\text { My working arrangements do not lead to much interference of work with } \\
\text { family life. }\end{array}$ & 3.49 & .951 & \\
\hline $\begin{array}{l}\text { My working arrangements allow me to sleep for adequate number of hours } \\
\text { and perform productively at work. }\end{array}$ & 3.45 & 1.139 & \\
\hline \multicolumn{4}{|l|}{ Job Satisfaction } \\
\hline & Mean & Std. Deviation & $\mathrm{N}$ \\
\hline I am overall satisfied with my job. & 3.55 & .879 & \multirow[t]{6}{*}{203} \\
\hline I am happy and do not intend to switch from my current job any soon. & 3.60 & .804 & \\
\hline $\begin{array}{l}\text { I am happy with my co-workers as they are cooperative and help others to } \\
\text { maintain a healthy work-life balance. }\end{array}$ & 3.72 & .805 & \\
\hline $\begin{array}{l}\text { I am satisfied with the management as it incorporates counseling services } \\
\text { to personally understand an employee's concerns. }\end{array}$ & 3.39 & .913 & \\
\hline $\begin{array}{l}\text { I am satisfied as the employees demonstrating high performances are } \\
\text { justly rewarded with bonus or other monetary benefits. }\end{array}$ & 3.88 & .850 & \\
\hline I am determined to establish my career in my current organiz & 3.47 & .976 & \\
\hline
\end{tabular}

As mentioned earlier, the questionnaire was constructed of 6 factors, covering 31 variables. Table 2 illustrates the mean and the standard deviation values of those variables. The mean values range from 3.13 to 4.22 for the variables composed, which signifies that tendency is more towards the scale of 'Neutral' to 'Strongly Agree'. The standard deviation for the same items is between 0.679 and 1.139. Among the four factors considered under the FWA, the mean values of the items under Flextime Schedule tend to be mostly higher than the values of the items under the other three factors namely Compressed Workweek, Telecommuting and Job Sharing which is in congruence with the study of Rawashdeh, Almasarweh and Jaber (2016), who associated the higher values under the item of flextime schedule with the fact that it is the oldest and the most widespread practice among the employees. 
Table 3: Reliability of Scale

\begin{tabular}{|l|l|l|}
\hline Variables & No. of Items & Cronbach's Alpha $(\boldsymbol{\alpha})$ \\
\hline Flextime Schedule & 5 & .734 \\
\hline Compressed Workweek & 5 & .655 \\
\hline Telecommuting & 4 & .630 \\
\hline Job Sharing & 4 & .616 \\
\hline Work-life Balance & 7 & .697 \\
\hline Job Satisfaction & 6 & .771 \\
\hline
\end{tabular}

Table 3 shows the reliability test which is conducted to confirm the internal consistency of the measures. Although there is no specific or determined lower value of Alpha $(\alpha)$, however, as per cited by George and Mallery (2003, p.231), “_>.9-Excellent, _>.8-Good,_> .7- Acceptable, _> .6-Questionable,_>.5-Poor, and $<.5$ - Unacceptable." Also, higher the value of $\bar{\alpha}$, the greater will be the reliability of the data (Tavagol and Dennick, 2011). In addition, according to Malhotra (2007), an Alpha ( $\alpha$ ) value of at least 0.60 can be considered to be acceptable where he suggested, the higher the score the greater will be the reliability of the data. In this study, all the values of Alpha are between .616 and .771 indicating that the components fall within the acceptable range. As a result, it could be inferred that these items from the questionnaire are valid and can be considered to be reliable for this research.

Table 4: Regression Analysis for hypothesis 1

\begin{tabular}{|c|c|c|c|}
\hline \multicolumn{4}{|l|}{ Regression Model } \\
\hline & $\operatorname{Beta}(\beta)$ & $\mathrm{t}$ & Sig. \\
\hline (Constant) & & 3.502 & .000 \\
\hline Flextime Schedule & .025 & .385 & .002 \\
\hline Compressed Workweek & .048 & .837 & .404 \\
\hline Telecommuting & .281 & 3.901 & .000 \\
\hline Job Sharing & .491 & 8.321 & .000 \\
\hline R Square $\left(\mathrm{R}^{2}\right)$ & .515 & & \\
\hline Adjusted $\mathrm{R}^{2}$ & .506 & & \\
\hline
\end{tabular}

Regression Analysis was carried out in order to test the hypotheses and to examine all the related variables more comprehensively for further validation of the study. Table 4 specifically aims to prove hypothesis 1 and it can be noticed that a positive relationship between all the factors of FWA (i.e. independent variables) and Worklife Balance (i.e. dependent variable) has been found. This is in congruence with the findings of the literature review where it was found that FWA can promote a better work-life balance (Shagvaliyeva and Yazdanifard, 2014, Frank and Lowe, 2003 and Hammer et al, 2005). However, one factor of FWA, i.e., Compressed Workweek $(\beta=.048, p=.404)$ could not be accepted, as the level of acceptance is $p<0.05$. Moreover, it can be said that the overall strength of association between the independent variables and the target variable is moderately significant with R-square value of .515 which indicates that $51.5 \%$ of the variation in Work-life Balance can be explained by the regression model.

Table 5: Regression Analysis for hypothesis 2

\begin{tabular}{|c|c|c|c|}
\hline \multicolumn{4}{|l|}{ Regression Model } \\
\hline & $\operatorname{Beta}(\beta)$ & $\mathrm{t}$ & Sig. \\
\hline (Constant) & & 2.671 & .000 \\
\hline Work-life Balance & .825 & 20.688 & .000 \\
\hline R Square $\left(\mathrm{R}^{2}\right)$ & .680 & & \\
\hline Adjusted $\mathrm{R}^{2}$ & .679 & & \\
\hline
\end{tabular}

Table 5 exhibits the regression analysis between Work-life Balance as the independent variable and Job Satisfaction as the dependent variable. The test was conducted in order to prove the second hypothesis and it has been found that a positive relationship exists between the two variables. This is characterized by the values $(\beta=.825$, $\mathrm{p}=.000$ ) which signifies that a moderately positive relationship exists between the two; owing to which it can be denoted that the better the balance between the employees' professional and personal lives, the greater will be their job satisfaction level. Furthermore, the R-square value implies that $63.4 \%$ of the variation in the job satisfaction is explained by work-life balance. 
Table 6: Regression Analysis for hypothesis 3

\begin{tabular}{|l|l|l|l|}
\hline \multicolumn{5}{|l|}{ Regression Model } & Beta $(\beta)$ & t & Sig. \\
\hline (Constant) & & 1.209 & .000 \\
\hline Flextime Schedule & .123 & 2.213 & .028 \\
\hline Compressed Workweek & .073 & 1.471 & .143 \\
\hline Telecommuting & .121 & 1.937 & .003 \\
\hline Job Sharing & .427 & 12.209 & .000 \\
\hline R Square $\left(\mathrm{R}^{2}\right)$ & .634 & \\
\hline Adjusted $\mathrm{R}^{2}$ & .627 & \\
\hline a. Dependent Variable: Job Satisfaction
\end{tabular}

In order to test the last hypothesis, regression analysis was conducted between FWA (i.e. independent variables) and Job Satisfaction (i.e. dependent variable) which has been illustrated in table 6. From the table it can be seen that, a moderately positive relationship exists between the independent variables and the dependent variable with R-square value of .634 which signifies that $63.4 \%$ of the variation in job satisfaction can be explained by the 4 factors of FWA. On the contrary, only one factor namely Compressed Workweek could not be accepted just like table 4 as it has values of $(\beta=.073, p=.143)$ which is not in line with the acceptance level of $p<0.05$. Again, this matches the findings of the prior researches which suggested a positive impact of FWA on job satisfaction of the employees (Omondi and K'Obonyo, 2018, McNall, Masuda and Nicklin, 2009).

A supplementary segment was added in the questionnaire with the aim to figure out the sectors where these female teachers would rather be employed if they based their employment decisions on the dimensions of FWA that promote a better work-life balance. According to the survey, more than $75 \%$ of the respondents marked "No" to one of the questions in the survey instrument which stated "Do you intend to switch your profession in future?" A related question was asked which stated "Which of the following sectors would you work if you want a more flexible life?" Among the multiple options given, the highest proportion, i.e., $24.1 \%$ of the respondents feel that Research \& Consultancy would have been a better option to maintain a greater flexibility. Intriguingly, a noteworthy percentage of the respondents marked that they would rather stick to their current profession which signifies that the higher education sector is still a considerable option for employment from the aspect of flexibility; the figure is 19.7 . In addition, $13.8 \%$ of the respondents deem that self-employment would aid to promote a greater flexibility in their lives. An interesting related finding was also observed from one of the secondary sources i.e. the Independent, which stated that despite being a male dominated country, Bangladesh is advancing noticeably in terms of women empowerment where many courageous women are excelling in Small and Medium Enterprises (SMEs) and more than $10 \%$ of the entrepreneurs are women in the country (Pramanik, 2018). The other options given were IT/Telecommunication, Hospitality, Banks/Financial Institutions and others where the lowest percentage of the respondents, only 3, perceive that working in Banks/Financial Institutions would provide them with greater flexibility. This can be related to one of the prior research where according to Rahman (2019), it was found that women working in the private banks of Bangladesh are experiencing low job satisfaction due to not being able to maintain a proper work-life balance.

\section{Conclusion and Further Scopes of Research:}

This study has identified that most of the independent variables, namely Flextime Schedule, Telecommuting and Job Sharing have significant influence on the dependent variables i.e. Work-life Balance and Job Satisfaction. In addition, Work-life Balance is also found to have positive relationship with Job Satisfaction. Hence, it can be stated that, if organizations strongly incorporates FWA then the employees would be able to maintain a balance between work and life which will be beneficial for the female employees and would lead to higher job satisfaction. Contrariwise, one of the factors, Compressed Workweek, is found to have no significant relationship with the dependent variables Work-life Balance and Job Satisfaction. Therefore, it can be concluded that all the hypotheses developed in this study have been proven right, but Work-life Balance or their Job Satisfaction level is not significantly influenced by Compressed Workweek, unlike other FWA factors. One limitation to point out regarding the study which could be considered if further research is conducted in related areas is the sample size, as more accurate data could possibly be accumulated if a greater number of respondents could be reached out to as well as surveying female teachers of public universities could help to gather better insights regarding the topic. Supposedly, more items could be added to the survey instrument in addition to the ones identified in this study which could lead to new factors, followed by a factor analysis to refine the groupings. Moreover, this study has only covered the female teachers in the higher education segment of the country and it is believed that a comparative analysis could be performed by comparing and contrasting the practices of FWA in diversified sectors including the primary and secondary levels of education where the women are employed. Consequently, this might not only help the women to compare and choose their preferred employment sectors from the outlook of flexibility, 
but also help the management of different sectors to understand the importance of FWA in order to promote a better work- life balance for higher job satisfaction levels among the employees which in turn will lead to positive employee attitudes. Hence, there is enormous scope of research because if the organizations in any given sector of Bangladesh or some other county want to sustain and thrive in the present competitive era, the factors of FWA need to be further explored for the employees to feel satisfied and give their full potentials at work.

\section{References}

1. Agarwal, P. (2018). How You Can Encourage More Women Into Your Workforce. Forbes. Retrieved from https://www.forbes.com/sites/pragyaagarwaleurope/2018/08/31/how-you-can-encourage-more-women-intoyour-workforce/\#47fda19073bb.

2. Allen, T. (2001). Family-Supportive Work Environments: The Role of Organizational Perceptions. Journal Of Vocational Behavior, 58(3), pp. 414-435. doi: 10.1006/jvbe.2000.1774.

3. Allen, T., Johnson, R., Kiburz, K., \& Shockley, K. (2012). Work-Family Conflict and Flexible Work Arrangements: Deconstructing Flexibility. Personnel Psychology, 66(2), pp. 345-376. doi: 10.1111/peps.12012.

4. Anuradha and Pandey, M. (2016). Impact of work-life balance on job satisfaction of women doctors. Problems and Perspectives in Management, 14(2), pp.319-324.

5. Apgar IV, M. (1998). The alternative workplace: Changing where and how people work, Harvard Business Review, 76(3), pp. 121-136.

6. Baltes, B., Briggs, T., Huff, J., Wright, J., \& Neuman, G. (1999). Flexible and compressed workweek chedules: A meta-analysis of their effects on work-related criteria. Journal of Applied Psychology, 84(4), pp. 496-513.

7. Baltes, B., Clark, M., \& Chakrabarti, M. (2009). Work-life balance: the roles of work-family conflict and work-family facilitation. In A. Lingley, S. Harrington, \& N. Page (Eds.), Handbook of Positive Psychology and Work. (pp. 491-521). New York, NY: Oxford University Press.

8. Bangladesh Education Statistics 2018(New). (2018). Retrieved from http://data.banbeis.gov.bd/.

9. Barber, C., Laing, A., \& Simeone, M. (2005). Global Workplace Trends: A North American and European Comparison. Journal of Corporate Real Estate, 7(3), pp. 210-221.

10. Bélanger, F. (1999). Workers' propensity to telecommute: An empirical study. Information \& Management, 35(3), pp. 139-153. doi: 10.1016/s0378-7206(98)00091-3.

11. Byron, K. (2005). A meta-analytic review of work-family conflict and its antecedents. Journal of Vocational Behavior, 67, pp. 169-198.

12. Cole, G. (2006). Flexibility and the Workplace: The Battle to Control Working Time. Managerial Law, 48(6), pp. 536-540.

13. Cullbreath, G. (2010). Flexible Work Arrangements: An Evaluation of Job Satisfaction and Work-Life Balance (Ph.D). Capella University.

14. Eick, C. (2002). Job sharing their first year: a narrative of two partnered teachers' induction into middle school science teaching. Teaching And Teacher Education, 18(7), pp. 887-904. doi: 10.1016/s0742051x(02)00049-5.

15. Frank, K., \& Lowe, J. (2003).An Examination of Alternative Work Arrangements in Accounting Practice, Accounting Horizons, 17(2), pp.139-151.

16. Fulmer, I., \& Ployhart, R. (2013). Our Most Important Asset. Journal Of Management, 40(1), pp. 161-192. doi: 10.1177/0149206313511271.

17. Gholipour, A., Bod, M., Zehtabi, M., Pirannejad, A., \& Kozekanan, S. (2010). The Feasibility of Job Sharing as a Mechanism to Balance Work and Life of Female Entrepreneurs. International Business Research, 3(3), p. 133. doi: 10.5539/ibr.v3n3p133.

18. Golden, T., \& Veiga, J. (2005). The Impact of Extent of Telecommuting on Job Satisfaction: Resolving Inconsistent Findings. Journal Of Management, 31(2), pp. 301-318. doi: 10.1177/0149206304271768.

19. Grantham, C., Swanberg, J., \& Johnson, R. (2009). Flexible Work Arrangements for Nonexempt Employees. Retrieved from https:/www.worldatwork.org/docs/research-and-surveys/worldatwork-sponsoredresearch/research-report-flexible-work-arrangements-for-nonexempt-employees.pdf.

20. Greenhaus, J., \& Allen, T. (2006). Work-family balance: Exploration of a concept. In The Families and Work Conference. Provo, UT.

21. Gregory, A., \& Milner, S. (2009). Editorial: Work-life Balance: A Matter of Choice?. Gender, Work \& Organization, 16(1), pp.1-13. doi: 10.1111/j.1468-0432.2008.00429.x.

22. Guest, D. (2002). Perspectives on the Study of Work-life Balance. Social Science Information, 41(2), pp.255279.

23. Hammer, L., Neal, M., Newsom, J., Brockwood, K., \& Colton, C. (2005). A Longitudinal Study of the Effects of Dual-Earner Couples' Utilization of Family-Friendly Workplace Supports on Work and Family Outcomes. Journal Of Applied Psychology, 90(4), pp. 799-810. doi: 10.1037/0021-9010.90.4.799. 
24. Hofäcker, D., \& König, S. (2013). Flexibility and work-life conflict in times of crisis: a gender perspective. International Journal Of Sociology And Social Policy, 33(9/10), pp. 613-635. doi: 10.1108/ijssp-04-20130042.

25. Kalliath, T., \& Brough, P. (2008). Work-Life Balance: A review of the meaning of the balance construct. Journal Of Management \& Organization, 14(3), pp. 323-327. doi: 10.5172/jmo.837.14.3.323.

26. Khatun, F. (2018). Women's participation in the job market. The Daily Star. [online] Available at: https://www.thedailystar.net/supplements/womens-participation-the-job-market-1545181 [Accessed 23 Feb. 2019].

27. Kotey, B. (2017). Flexible working arrangements and strategic positions in SMEs. Personnel Review, 46(2), pp. 355-370. doi: 10.1108/pr-04-2015-0089.

28. Kumari, L. (2012).Employees Perception Work Life Balance and its relation with Job Satisfaction in Indian PSU, IJEMR, 2(2), pp. $2249-8672$.

29. Kumari, L. (2012).Employees Perception Work Life Balance and its relation with Job Satisfaction in Indian PSU, IJEMR, 2(2), pp. $2249-8672$.

30. Malhotra, N. (2007).Marketing Research: an Applied Orientation. USA, Pearson Prentice Hall.

31. Mamaghani, F. (2006). Impact of Information Technology on the Workforce of the Future: An analysis. International Journal of Management, 23(4), pp. 845-850.

32. Maxwell, G., Rankine, L., Bell, S., \& MacVicar, A. (2007). The Incidence and Impact of FWAs in Smaller Businesses. Employee Relations, 29(2), pp. 138-161.

33. McNall, L., Masuda, A., \& Nicklin, J. (2009). Flexible Work Arrangements, Job Satisfaction, and Turnover Intentions: The Mediating Role of Work-to-Family Enrichment. The Journal of Psychology, 144(1), pp. 6181. doi:10.1080/00223980903356073.

34. Meenakshi, S., Subrahmanyam, V. and Ravichandran, K. (2013). The Importance of Work-LifeBalance. IOSR Journal of Business and Management (IOSR-JBM), [online] 14(3), pp.31-35. Available at: http://www.iosrjournals.org/iosr-jbm/papers/Vol14-issue3/F01433135.pdf [Accessed 18 Feb. 2019].

35. Mokhtarian, P. (1991). Institute of Transportation Studies. California: University of California, Davis. Retrieved from https://www.researchgate.net/publication/46439796_Defining_Telecommuting

36. Narayana, M. and Neelima, J. (2018). Work life balance on women employees in banking sector: An empirical perspective. International Journal of Advanced Educational Research, 2(5), pp.58-61.

37. Nilles, J. (1988). Traffic reduction by telecommuting: A status review and selected bibliography. Transportation Research Part A: General, 22(4), pp. 301-317. doi: 10.1016/0191-2607(88)90008-8.

38. Norman, P., Collins, S., Conner, M., Martin, R., \& Rance, J. (1995). Attributions, Cognitions, and Coping Styles: Teleworkers' Reactions to Work-Related Problems. Journal Of Applied Social Psychology, 25(2), pp. 117-128. doi: 10.1111/j.1559-1816.1995.tb01587.x.

39. Omondi, A., K'Obonyo, P. (2018). Flexible work schedules: A critical review of literature. The Strategic Journal of Business \& Change Management, 5(4), pp. 2069 - 2086.

40. Ovi, I. (2018). Women in workforce: Employment without empowerment. Dhaka Tribune. [online] Available at: $\quad$ https://www.dhakatribune.com/business/2018/03/08/women-workforce-employment-withoutempowerment [Accessed 16 Feb. 2019].

41. Pahuja, S. (2016). Work Life Balance of Female Employees: A Case Study. International Research Journal of Management and Commerce, [online] 3(12), pp.41-50. Available at: https://www.researchgate.net/publication/312385528_WORK_LIFE_BALANCE_OF_FEMALES_EMPLO YEES_A_CASE_STUDY [Accessed 17 Feb. 2019].

42. Palmeri, $\overline{\mathrm{S}}$. (2013). Surviving a reduction in force: The impact of flexible work arrangements on employee job satisfaction and work/life balance following the 2008 recession (Ph.D). Capella University.

43. Paull, M., Omari, M., \& Sharafizad, F. (2009). Flexible Work Arrangements In Higher Education: A Tale of Two Groups. ANZAM. Retrieved from https://www.anzam.org/wp-content/uploads/pdfmanager/1082 ANZAM2009-021.PDF.

44. Pierce, J., Newstrom, J., Dunham, R., \& Barber, A. (1989). Alternative work schedules. Boston: Allyn and Bacon.

45. Pramanik

S. (2019)

The

Independent.

Retrieved

from http://www.theindependentbd.com/printversion/details/175224.

46. Rahman, M. (2019). Work- Life Balance as an Indicator of Job Satisfaction Among the Female Bankers in Bangladesh. European Journal Of Business And Management, 6(11), pp. 9-14. doi: 10.7176/ejbm/11-6-03.

47. Ralston, D. (1989). The benefits of Flextime: Real or imagined? Journal Of Organizational Behavior, 10(4), pp. 369-373. doi: 10.1002/job.4030100407.

48. Rane, D. (2011). Employee Job Satisfaction: An Essence of Organization. HRM Review, XI(7). Retrieved from https://pdfs.semanticscholar.org/defa/659c3154666b03c3c7d7399c0b794ce7edef.pdf.

49. Rau, B. and Hyland, M. (2002). Role conflict and flexible work arrangements: the effect on applicant 
attraction. Personnel psychology, 55(1), pp. 111-136.

50. Rawashdeh, A., Almasarweh, M., \& Jaber, J. (2019). Do Flexible Work Arrangements Affect Job Satisfaction And Work-Life Balance In Jordanian Private Airlines? International Journal Of Information, Business And Management, 8(3), pp. 173-185. Retrieved from https://www.researchgate.net/publication.

51. Raziq, A., \& Maulabakhsh, R. (2015). Impact of Working Environment on Job Satisfaction. Procedia Economics And Finance, 23, pp. 717-725. doi: 10.1016/s2212-5671(15)00524-9.

52. Ronen, S. and Primps, B. (1981). The Compressed Work Week as Organizational Change: Behavioral and Attitudinal Outcomes. Academy of Management, 6(1), pp. 61-74.

53. Russell, H., O'Connell, P., \& McGinnity, F. (2009). The Impact of Flexible Working Arrangements on Worklife Conflict and Work Pressure in Ireland. Gender, Work \& Organization, 16(1), pp. 73-97. doi: 10.1111/j.1468-0432.2008.00431.X.

54. Scordato, C., \& Harris, J. (1990). Workplace flexibility. HR Magazine, 35(1), pp.75-78.

55. Scott, S. Advantages \& Disadvantages of Flextime. Retrieved from https://smallbusiness.chron.com/advantages-disadvantages-flextime-11642.html.

56. Shagvaliyeva, S., \& Yazdanifard, R. (2014). Impact of Flexible Working Hours on Work-Life Balance. American Journal Of Industrial And Business Management, 4(01), pp. 20-23. doi: 10.4236/ajibm.2014.41004.

57. Shapiro, D., Furst, S., Spreitzer, G., \& Von Glinow, M. (2002). Transnational teams in the electronic age: are team identity and high performance at risk? Journal Of Organizational Behavior, 23(4), pp. 455-467. doi: 10.1002/job.149.

58. Sharafizad, F., Paull, M., \& Omari, M. (2011). Flexible work arrangements: Accessibility in a university environment. Australian Universities' Review, 53(2), pp. 43-49.

59. Spector, P. (1997). Job Satisfaction: Application, Assessment, Causes, and Consequences. London: Sage.

60. Sundaresan, S. (2014). Work-Life Balance - Implications for Working Women. OIDA International Journal of Sustainable Development, [online] 7(7), p.102. Available at: https://papers.ssrn.com/sol3/papers.cfm?abstract_id=2505439 [Accessed 18 Feb. 2019].

61. Tavakol, M. and Dennick, R. (2011). Making sense of Cronbach's alpha. International Journal of Medical Education, 2, pp.3-55.

62. University Grants Commission of Bangladesh. (n.d.). [online] Available at: http://old.ugc.gov.bd/home/search?title=public+universities [Accessed 18 Feb. 2019].

63. Vroom, V. (1964). Work and motivation. New York: Wiley.

64. Workplace Flexibility. (2010). Retrieved https://scholarship.law.georgetown.edu/cgi/viewcontent.cgi?article=1009\&context=legal. 